\title{
On-the-Job Training and Human Resource Management: How to Improve Competitive Advantage of an Organization?
}

\author{
Kosovka Ognjenović \\ Institute of Economic Sciences, 12 Zmaj Jovina Str., 11000 Belgrade, Serbia, \\ kosovka.ognjenovic@ien.bg.ac.rs
}

\begin{abstract}
Background: In this paper, the effects of four groups of factors on organizational performance are examined. Those are human resource management (HRM) policies and practices, financial and business indicators, location, and firm characteristics. A review of selected literature confirmed that a similar set of factors, through its positive effects on boosting organizational performance, may significantly improve competitive advantage of firms.

Methods: An empirical analysis using firm-level data is conducted on the sample of enterprises operating in Serbia. A microeconometric approach is employed in order to specify and estimate empirical models. Two statistical models are applied. The ordered probit model is used for investigating organizational performance and the standard binary probit model for examining the decision of a firm to integrate the human resource development (HRD) department into its organizational structure. The goodness of fit measures confirmed the statistical reliability of estimated models.

Results: Estimation results revealed that optimization of the number of employees, sales and revenues, firm age, increased market demand and competitive environment, as well as the 'right decisions' of the top management have significantly positive effects on boosting organizational performance. Significance of on-the-job training for boosting organizational performance was not empirically supported. In the same group of factors are firm size, industry and region. An auxiliary model shown that large- and medium-sized firms, firms with high level of revenues, privately owned, foreign and those located in or near to the capital city are more likely to have HRD departments.

Conclusions: This paper provides a survey of the theoretical literature and explains empirical findings that are relevant for understanding to what extent on-the-job training, managing human resource, as well as some other internal and external organizational and financial factors are important for enhancing competitive advantage of firms.
\end{abstract}

Keywords: training, human resource management, competitiveness, organization, employees

\section{Introduction}

The transitional path of Serbia differs from the paths of the most of other countries of Central and Eastern Europe. Transition to a market economy, which started at the end of the 1980s, was disrupted almost at its onset due to the considerable political and economic turmoil during the 1990s. This unfavourable development impeded transitional reforms and caused Serbia to lag significantly behind the rest of the European transitional countries (Cerović, 2006). The political change that occurred at the beginning of the 2000s reopened the agenda of extended economic and social reforms. As many other European transitional countries, Serbia lost a significant amount of employment, especially during the privatization phase that was initiated by the adoption of the new privatization regulation in 2001. Beside the decline in the employment, the effects of the privatization have been also manifested through changes in the structure of the corporate sector in Serbia.

Namely, while the number of medium- and large-sized firms was reduced, the number of small-sized privately owned enterprises was increased (Jovičić, 2005). According

Received: November 4, 2014; revised: December 16, 2014; accepted; January 12, 2015 
to achievement indicators of the main areas of transitional reforms, Serbia is today rated as an emerging European transitional country together with FYR Macedonia and Montenegro (EBRD, 2013).

The privatization process introduces changes in the organizational structure and the functioning of firms in transitional economies (Cooke, Wood, Psychogios, \& Szamosi, 2011); (Horwitz, 2011 ). Due to competitive pressures, old rigid organizational structures have to be changed into the modern and flexible ones (Zupan \& Kaše, 2005). Skills and competences of the labour force became important elements for enhancing competitiveness (European Commission, 2014); (World Economic Forum, 2014) and economic growth (Blundell, Dearden, Meghir, \& Sianesi, 1999); (Nelson \& Phelps, 1966); (Romer, 1990). This permanent competition among countries is especially visible when comparisons at the national level are observed. Furthermore, some empirical studies conducted at the firm (Dany, Guedri, \& Hatt, 2008) and individual level (Grund \& Martin, 2012) in advanced western economies confirmed the importance of human resource management (HRM) functions and further training for boosting competitive advantages, in particular, throughout their linkages with organizational performance.

The aim of this paper is to examine the effects of four groups of factors on boosting organizational performance of firms in Serbia. Those are HRM policies and practices, financial and business indicators, location, and firm characteristics. Based on theoretical elaboration (Cooke, Wood, Psychogios, \& Szamosi, 2011); (Dany, Guedri, \& Hatt, 2008); (Horwitz, 2011 ); (Judge, Naoumova, \& Douglas, 2009); (Sung \& Choi, 2014); (Zupan \& Kaše, 2005), it is expected that these factors, throughout their positive effects on organizational performance, may significantly improve competitive advantage of firms. In addition, an auxiliary model was estimated. Based on this model, the factors that affect the decisions of firms to integrate human resource development (HRD) departments into their organizational structure are explored. This research question is observed in the light of the fact that the support to business development requires a strategic approach to HRM on the level of an organization (Bahtijarević Šiber, 1999); (Zupan $\&$ Kaše, 2005). In order to conduct the firm-level empirical analysis, the microeconometric approach is applied.

The following section provides the theoretical background for the empirical research and the main hypotheses. Section 3 contains the research methodology and describes the data sources and the analytical methods used for research purposes. Estimation results derived by the empirical models are given in section 4, as well as their discussion. The last section recapitulates the main findings and concludes the paper.

\section{Theoretical background and hypothe- ses formulation}

There is a body of theoretical and empirical literature that supports the hypothesis that HRM in a broader sense should be considered as an integral part of business strategies in organizations (Becker \& Gerhart, 1996); (Dany, Guedri, \& Hatt, 2008). This is especially applicable in transitional countries where firms underwent corporate restructuring in order to establish modern and market oriented organizations (Zupan \& Kaše, 2005). Following these ideas, we can formulate appropriate hypothesis.

Hypothesis 1: HRM in firms operating in transitional economies have to be changed so that policies and practices related to expansion and reduction of employees, to training and development, as well as to recruitment and retention of skilled and/or unskilled workers positively affect organizational performance.

Human resources are important element of sustained competitive advantage of an organization (Barney, 1995); (Barney \& Clark, 2007). Because they form intangible resources 'that are hard to imitate' by other organizations, investment in human capital is expected to stimulate employee commitment and accordingly to improve business performance (Dany, Guedri, \& Hatt, 2008, p. 2097). However, the effects of investments can be examined from different perspectives regarding the costs and returns induced by training. Following the standard Mincer's approach, from the perspective of an employee, on-the-job training can be observed as an investment in future wages (Mincer, 1962).

But, from the perspective of the employer, on-the-job training can also be interpreted as an investment and as a cost (Acemoglu \& Pischke, 1998); (Bartel, 2000). The theory of human capital also implies that firms cannot expect large benefits from providing their employees with general training (Becker, 1962). In other words, only specific training or on-the-job training can bring certain benefit to the firm. However, this assumption is later relaxed because under the circumstances of pronounced technological change and the intensification of competitive pressures the need for training in firms and of employees is more required than before (Acemoglu \& Pischke, 1999); (Grund \& Martin, 2012).

Empirical studies provide valuable findings regarding trainings provided by firms (Barron, Berger, \& Black, 1999). They have positive effects on productivity increase (Barrett \& O'Connell, 2001), provide more benefits to firms if high skilled workers are trained (Mincer, 1994), give 'monopsony power' to those firms that train their workers (Acemoglu \& Pischke, 1998, p. 80), etc. Moreover, training opportunities provided by firms are part of 'job resources' that help workers to mitigate 'job demands' (OECD, 2014, p. 104). From some recent comparative research studies one may conclude that returns on firm's investment in training are significant 
and follow an increasing trend (Bartel, 2000), but also that more research effort is needed in order to improve accuracy and reliability of previous empirical findings (Barrett \& O'Connell, 2001).

In this paper, we are thus interested in on-the-job-training or training that is usually organized at the 'trainee's place of work' (Chatzimouratidis, Theotokas, \& Lagoudis, 2012). However, the data source, used for conducting the empirical analysis, under the term 'investment in on-the-job-training' considers a broader set of activities, such as participation in training, attending seminars and access to the professional literature. Certain empirical analyses confirm that about half of all trainings are organized in the course of employee's work (Chatzimouratidis, Theotokas, \& Lagoudis, 2012, p. 666), whereas the results of the Cranet survey show that firms allocate between 2 and 5 percent of the annual payroll costs on trainings and HRD (CRANET, 2011, p. 60).

It is expected that the majority of firms have some business or development plan. The increased level of market demand for products or services and favourable competitive environment can be considered the factors that have direct implications for financial performance of firms (Sung \& Choi, 2014). Furthermore, the motives of top managers to boost business performance are related to the compensations they could expect to receive (Gerhart \& Milkovich, 1990); (Jensen \& Murphy, 1990), but also profit of firms remains an important goal, as well as the influence their decisions may have on the overall organizational outcomes (Finkelstein \& Hambrick, 1990). This view is not new and it is related to the managerial discretion theory (Williamson, 1963) and managers' ability to initiate strategic activities in organizations (Finkelstein \& Peteraf, 2007). This can be empirically tested.

Hypothesis 2: The commitment of the top management to implement strategic business policies that lead to the increase in market demand in a competitive environment positively affects overall organizational performance and enhances competitive advantage of an organization.

There are empirical evidences that reveal that geographical location or region can substantially improve competitive advantage of an organization (Judge, Naoumova, \& Douglas, 2009). This is why, especially in transitional economies, central regions are better connected with the rest of the territory, have better access to the infrastructure, including both 'hard' and 'soft' infrastructure, have more opportunities to make formal and informal contacts with authorities, etc. This can be posted as a hypothesis.

Hypothesis 3: Geographical location in or near to the capital city positively affects organizational performance.

The fourth group of factors include organizational characteristics, such as firm age, firm size, industry, ownership, and origin of capital. Business performances of the private enter- prises are under stronger influence of competitors than those of the state-owned enterprises, because the latter are not lead by profit goals. Consequently, firms in the private ownership, as well as those established by foreign capital are more interested in enhancing business performance. On the other hand, the previous research studies revealed that competitive dynamics of firms vary substantially by the organizational size and economic sector (Judge, Naoumova, \& Douglas, 2009). Opportunities for human resource development are more frequent in the service sector (Sung \& Choi, 2014). Furthermore, due to organizational capability for change it is assumed that firm age and organizational performance follow a 'u-shaped' relationship. Based on previous elaboration, the hypothesis can be derived.

Hypothesis 4: Organizational characteristics, such as firm age, firm size, industry, ownership, and origin of capital are significantly and positively related to organizational performance.

The final hypothesis, which claims that organizational characteristics, as well as certain financial indicators have statistically significant and positive influence on a firm's decision to integrate a HRD department into its organizational structure, will be empirically tested. In order to conduct this part of the empirical research an auxiliary model will be constructed.

\section{Research methodology}

\subsection{Data}

The data used in this analysis result from joint research of the Public Employment Service (PES) of Serbia and the Institute for Economic and Social Policy Research, which was conducted in order to investigate the labour market demand for specific occupations and skills. The data are collected in March (and April) 2009 surveying active firms operating in Serbia. Survey design and the process of data collection are described in detail in a research study (Institute for Economic and Social Policy Research, et al., 2009). The aim of this survey was twofold. On one hand, to increase capacities of managerial and advisory staff of the PES and to make contacts with potential employers in order to have better insights into their needs, and on the other hand, it was a part of activities in the area of the employment policy priorities that are directly related to the European integration process of Serbia.

Strictly speaking, the specific aim of this research was to establish a survey that would have a similar role to Cedefop research for European countries, including Norway and Switzerland (Cedefop, 2010). In both cases, the purpose of these research initiatives was similar. The analysis intends to provide up to date information on the labour market needs so that skills and competencies of the labour force can meet 
present and future requirements induced by technological change and global competition.

To the best knowledge of the author, the data set used for the empirical analysis in this paper is the only statistically representative data set available at the firm level in Serbia. The fact that survey data come from 2009 does not undervalue the results of the empirical analysis from current perspective. This view can be additionally supported by the assessment of the competitive position of Serbia in the light of the international comparison. While in 2009 Serbia was rated as a country at the second stage of development, i.e. positioned among the efficiency-driven economies (World Economic Forum, 2009, p. 12), this situation has not changed because the Serbian economy stayed at the same group even several years later (World Economic Forum, 2014, p. 11).

In addition, this data set was used because it also includes financial performance data. It is worth emphasizing that beside sections of the questionnaire that were created to gather data about present and future employers' needs for workers of particular occupations and skills, as well as about present job vacancies and employers' opinions regarding difficulties to recruit workers of appropriate competences and abilities, included in the questionnaire was a set of questions on firm business performance. This section included questions about decisions made within firms, such as whether a firm has the HRD department, whether a firm has and applies its HRM strategy or whether a firm invests in the development of human potential and what portion it allocates to training of its employees on an annual basis. More precisely, the data were collected for the year 2008, and so it is assumed that the influence of the 2009-2010 recession was not contained in survey data.

Data resources for empirical studies on HRM practices in Serbia are scarce. Serbia, for instance, does not participate in the European Working Conditions Survey on present practices related to job demands and job resources (Eurofound, 2012), which provides comparative data at the European level, including Member States, candidates and potential candidates. It is a valuable resource for studying the possibilities of employees to participate in on-the-job training and other trainings paid for or organized by their firms. Serbia has participated in the 2008-2010 Cranet survey that provides detailed comparative data on HRM policies and practices in large organizations (CRANET, 2011). However, a low response rate to the Cranet survey diminishes the value of this survey for empirical research in case of Serbia (Svetlik, et al., 2010, p. 822).

Some further research studies on HRM policies and practices will benefit from the new cycle of data collection based on the Cranet survey that has started in 2014, because the sample of firms from Serbia is expanded to 100 large organizations. Also, longitudinal data would be more useful, so that one can observe the changes in HRM policies and practices, in particular having in mind that the
Serbian economy is still under transitional reforms pressure.

Survey data used in this paper are based on a stratified random sample of firms drawn from the Statistical Business Register in the Statistical Office of Serbia. A (3x14) matrix of spatial and industrial strata was constructed. Three macro regions were determined, where one of them represented the capital city. In order to avoid skewness in the distribution of enterprises and to mitigate the potential rate of nonresponses, only firms that have 5 and more employees are included in the sample. Both private and public enterprises that provide commercial and public services are inserted in the sample, but civil servants and those employed in armed forces are excluded. Economic activities are represented in the sample based on the prevalent activity of a firm and are determined according to the NACE (Revision 1) codes.

The total number of sample units that were realized throughout the field work consists of 794 firms which form observations for our analysis, i.e. $i=1, \ldots, n, n=794$. However, some of the variables used in the empirical analysis contained missing data. After deleting missing observations the sample size is accordingly reduced (see Table 1). The response rate to the survey was nearly 60 percent. This response rate can be considered as satisfactory having in mind business uncertainties that may have been induced by the economic crisis effects, as well as by regular activities on preparing the annual financial reports in the first quarter of every year.

Table 1 reports summary statistics for the variables used in the empirical analysis, whereas Table $1 \mathrm{~A}$ in the Appendix presents a correlation matrix.

In what follows, the empirical models will be specified and the variables used for research purposes will be described.

\subsection{Empirical models}

The first empirical model is a model on organizational performance which is constructed in a form of ordered probit following the theoretical expression given in Greene (Greene, 2000 , pp. 875-878). This model is observed through two empirical specifications. Firstly, we observed the relationship between organizational performance (OP) and HRM policies and practices in terms of the changes in employment, e.g. expansion or reduction of the number of employees (ChEmp), investment in on-the-job training (OJT) and recruitment of both skilled (RecruSkill) and unskilled (RecruUnskill) workers. This model is given in the form: 
Table 1: Descriptive statistics. Source: Author's calculation.

\begin{tabular}{|c|c|c|c|c|c|}
\hline Variable & Observations & Mean & Std. Dev. & Min & Max \\
\hline \multicolumn{6}{|l|}{$H R M$} \\
\hline HR Strategy, yes=1 & 794 & 0.159 & 0.366 & 0 & 1 \\
\hline HR Department, yes $=1$ & 794 & 0.160 & 0.367 & 0 & 1 \\
\hline On-the-job training & 716 & 0.005 & 0.025 & 0 & 0.360 \\
\hline Change in employment & 716 & 1.046 & 0.271 & 0.044 & 3.000 \\
\hline \multicolumn{6}{|l|}{ Recruitment of workers } \\
\hline Skilled & 497 & 2.669 & 0.687 & 1 & 3 \\
\hline Unskilled & 497 & 2.742 & 0.594 & 1 & 3 \\
\hline \multicolumn{6}{|l|}{ Business indicators } \\
\hline Organizational performance & 716 & 1.626 & 0.793 & 1 & 3 \\
\hline Log of revenues & 716 & 11.997 & 1.687 & 7.404 & 18.369 \\
\hline Market \& Competition & 716 & 2.289 & 1.022 & 1 & 5 \\
\hline Management & 716 & 3.754 & 0.760 & 1 & 5 \\
\hline \multicolumn{6}{|l|}{ Region } \\
\hline Capital city & 716 & 0.314 & 0.464 & 0 & 1 \\
\hline Region North & 716 & 0.354 & 0.479 & 0 & 1 \\
\hline Region South (ref.) & 716 & 0.331 & 0.471 & 0 & 1 \\
\hline Type of settlement, city $=1$ & 716 & 0.370 & 0.483 & 0 & 1 \\
\hline \multicolumn{6}{|l|}{ Characteristics of organization } \\
\hline Ownership, private $=1$ & 716 & 0.873 & 0.333 & 0 & 1 \\
\hline Origin of capital, foreign $=1$ & 716 & 0.120 & 0.325 & 0 & 1 \\
\hline Age, in years & 716 & 19.788 & 19.456 & 2 & 170 \\
\hline $\mathrm{Age}^{2} / 100$ & 716 & 7.695 & 19.579 & 0.04 & 289 \\
\hline \multicolumn{6}{|l|}{ Size of organization } \\
\hline Large & 716 & 0.130 & 0.336 & 0 & 1 \\
\hline Medium & 716 & 0.271 & 0.448 & 0 & 1 \\
\hline Small & 716 & 0.443 & 0.497 & 0 & 1 \\
\hline $\operatorname{Micro}(r e f)$. & 716 & 0.156 & 0.364 & 0 & 1 \\
\hline \multicolumn{6}{|l|}{ Industry } \\
\hline Manufacturing & 716 & 0.229 & 0.420 & 0 & 1 \\
\hline Construction & 716 & 0.147 & 0.354 & 0 & 1 \\
\hline Services & 716 & 0.567 & 0.496 & 0 & 1 \\
\hline Agriculture (ref.) & 716 & 0.057 & 0.233 & 0 & 1 \\
\hline
\end{tabular}

Statistical software Stata 11.0 is used for the econometric analysis of data. 
$\mathrm{OP}_{\mathrm{i}}=\beta_{1}$ ChEmp $_{\mathrm{i}}+\beta_{2} \mathrm{OJT}_{\mathrm{i}}+\beta_{3}$ RecruSkill $_{\mathrm{i}}+\beta_{4}$ RecruUnskil$l_{\mathrm{i}}+\mathrm{u}_{\mathrm{i}}$,

$\left\{\mathrm{OP}_{\mathrm{i}}\right\}_{1}^{\mathrm{J}}, \mathrm{i}=1, \ldots, \mathrm{n}, \mathrm{J}=1,2,3$.

The previous model is then expanded by adding new explanatory factors as we will explain below:

$\mathrm{OP}_{\mathrm{i}}=\beta_{1} \mathrm{OJT}_{\mathrm{i}}+\beta_{2}$ Size $_{\mathrm{i}}+\beta_{3}$ Private $_{\mathrm{i}}+\beta_{4}$ Foreign $_{\mathrm{i}}+\beta_{5}$ Age $_{\mathrm{i}}+\beta_{6}$ $\mathrm{Age}_{\mathrm{i}}{ }_{\mathrm{i}}+\beta_{7} \operatorname{lnRev}_{\mathrm{i}}+\beta_{8}$ MarCom $_{\mathrm{i}}+\beta_{9}$ Management $_{\mathrm{i}}+\gamma_{\mathrm{k}} \mathrm{z}_{\mathrm{ik}}+\varepsilon_{\mathrm{i}}$, $\left\{\mathrm{OP}_{\mathrm{i}}\right\}_{1}^{\mathrm{J}}, \mathrm{i}=1, \ldots, \mathrm{n}, \mathrm{J}=1,2,3$.

The dependent variable $(O P)$ in both empirical specifications (1a) and (1b) is constructed based on the self-assessed organizational performance of interviewed firms. An ordinal scale is used to range the values of the dependent variable from 1 (declining level of business performance) to 3 (increasing level of business performance), while a category 2 denotes those who responded that no changes occurred in their business performance. In other words, these three types of answers stand for 'poor', 'the same' and 'good' business performance of firms reported for the year 2008 in comparison with 2007.

This model is explained by a set of independent variables that include: the share of investments allocated to on-the-job training (OJT) in 2008 that indicates does the firm management implement HRM policies on training and development, the dummy variables for firm size (Size), firm ownership (Private) and origin of capital (Foreign), then, firm age in years (Age), firm age in years squared $\left(\mathrm{Age}^{2}\right)$, the log of annual revenues ( $R e v$ ) realized in 2008, as well as two categorical variables that indicate self-assessed influence of market demand and potential competition (MarCom) and of the management of firms (Management) on business performance in 2008.

The measuring scale for categorical variables MarCom and Management is ranged from 1 (extremely negative influence) to 5 (extremely positive influence). The contains all other independent variables that may be inserted in the empirical model (1b) during the estimation phase. It is assumed that is i.i.d. random variable. This term captures all other unobserved factors and possible uncertainties that can influence organizational performance. Finally, and are unknown regression parameters.

The second empirical model (2) is expressed in the form of a binary probit model (Greene, 2000, pp. 812-816). This econometric specification models the decision of a firm to choose a strategic approach in formulating and implementing HRM policies and practices. More precisely, a binary dependent variable indicates whether the firm has developed a strategy or a plan for managing human resource development in its organizational environment. However, during empirical data modelling, it is found that almost the same firms that have HRD departments also have a plan or a HRD strategy, which can be shown by a high and statistically significant correlation coefficient $r=0.723, \mathrm{p}<0.01$ (see Table $1 \mathrm{~A}$ in the Appendix). Furthermore, the variable that indicates whether the interviewed firm has integrated the HRD department into its organizational structure provides a better fit for the model as we will see in the following section. Thus, this variable will be used as a dependent variable (SHRM). The binary probit model is specified as follows:

$\mathrm{SHRM}_{\mathrm{i}}=\alpha_{0}+\alpha_{1}$ Age $_{\mathrm{i}}+\alpha_{2}$ Age $_{\mathrm{i}}+\alpha_{3}$ Size $_{\mathrm{i}}+\alpha_{4}$ Private $_{\mathrm{i}}+\alpha_{5}$ For$\operatorname{eign}_{\mathrm{i}}+\alpha_{6} \operatorname{lnRev}_{\mathrm{i}}+\lambda_{\mathrm{k}} \mathrm{z}_{\mathrm{ik}}+\zeta_{\mathrm{i}}, \mathrm{i}=1, \ldots, \mathrm{n}$.

In a standard binary choice model, the dependent variable takes on value 1 if outcome is realized and 0 otherwise. Predictors for this model include independent variables, such as a nonlinear term firm age in years that includes age (Age) and age squared $\left(\mathrm{Age}^{2}\right)$, then organizational size (Size) in 2008 (end-of-year data) constructed as a categorical variable that includes four dummies that capture micro, small-, mediumand large-sized organizations defined according to accounting and financial standards, a dummy variable that indicates whether the firm is privately held (Private), a dummy variable that denotes whether the firm is founded by foreign capital (Foreign), the log of annual revenues ( $R e v)$ realized in 2008 and the remaining independent variables including, for instance, the sector of economic activity of firms, geographical location of firms and alike. Standard normal results are ensured if the i.i.d. assumption about the stochastic term is correct. As before, and are unknown regression parameters to be estimated.

Interacted terms are not included in the empirical model specifications (1a), (1b) and (2) in order to avoid multicolinearity.

The theoretical framework and hypotheses that will be tested based on the empirical analysis are already derived in section 2. In the following section, estimation results for the three econometric specifications are presented.

\section{Estimation results and discussion}

\subsection{Results for the organisational performance model}

Estimation results for the ordered probit models are reported in Table 2. Two econometric specifications (1a) and (1b) for the organisational performance model are estimated. For the identification purposes, in both models the intercepts are excluded and the standard deviations of the error terms are set at 1 (Greene, 2000). Three outcomes of the dependent variable are determined as already elaborated in section 3.2. Those three outcomes are relabelled into outcomes 0,1 and 2. Thus, outcome 0 captures firms with poor business per- 
formance; outcome 1 represents firms with stable business performance which is divided by the threshold parameter (or a cut point 1) relabelled as constant 1 in Table 2; and outcome 2 captures firms with growing business performance divided by constant 2 depicted in Table 2 . The LR test rejected the null hypothesis of no significant differences between the two constants for both estimated models $\left[\chi^{2}(1)=125.28, \mathrm{p}<0.00\right.$; $\chi^{2}(1)=198.98, \mathrm{p}<0.00$ ], implying that the threshold parameters are different and statistically significant at conventional levels. This test provides a confirmation that the choice to use the ordered probit analysis is valid.

Table 2: Ordered probit estimates (dependent variable: Organizational performance). Source: Author's calculation.

\begin{tabular}{|c|c|c|c|c|c|c|}
\hline \multirow[b]{2}{*}{ Variable } & \multicolumn{3}{|c|}{ Model [1a] } & \multicolumn{3}{|c|}{ Model [1b] } \\
\hline & Coefficient & $\begin{array}{l}\text { Standard } \\
\text { Error }\end{array}$ & $\begin{array}{l}\text { Marginal } \\
\text { Effects }\end{array}$ & Coefficient & $\begin{array}{l}\text { Standard } \\
\text { Error }\end{array}$ & $\begin{array}{l}\text { Marginal } \\
\text { Effects }\end{array}$ \\
\hline Change in employment & $1.364 *$ & 0.396 & 0.520 & $1.354 *$ & 0.322 & 0.526 \\
\hline On-the-job training & 0.054 & 0.036 & 0.021 & -0.017 & 0.022 & -0.006 \\
\hline Skilled & -0.072 & 0.120 & -0.027 & & & \\
\hline Unskilled & $0.228 * * *$ & 0.136 & 0.087 & & & \\
\hline Urban settlement & & & & $-0.414^{*}$ & 0.161 & -0.162 \\
\hline Large organization & & & & 0.160 & 0.273 & 0.061 \\
\hline Medium organization & & & & -0.038 & 0.181 & -0.015 \\
\hline Small organization & & & & -0.090 & 0.142 & -0.035 \\
\hline Micro organization & & & & - & - & - \\
\hline Private ownership & & & & 0.227 & 0.142 & 0.089 \\
\hline Foreign capital & & & & -0.165 & 0.148 & -0.065 \\
\hline Age & & & & $-0.015 * *$ & 0.006 & -0.006 \\
\hline $\mathrm{Age}^{2} / 100$ & & & & $0.012 * *$ & 0.006 & 0.005 \\
\hline Log of revenues & & & & $0.207^{*}$ & 0.041 & 0.081 \\
\hline Market \& Competition & & & & $0.128 *$ & 0.049 & 0.050 \\
\hline Management & & & & $0.200 *$ & 0.061 & 0.078 \\
\hline Constant 1 & $0.926 * *$ & 0.478 & & $3.625^{*}$ & 0.596 & \\
\hline Constant 2 & $1.616^{*}$ & 0.491 & & $4.418 *$ & 0.604 & \\
\hline $\begin{array}{l}L R \text { test } \mathrm{H}_{0}: \text { constants are } \\
\text { equal }\end{array}$ & \multicolumn{3}{|c|}{$\chi^{2}(1)=125.28, p<0.00$} & \multicolumn{3}{|c|}{$\chi^{2}(1)=198.98, p<0.00$} \\
\hline Observations & 497 & & & 716 & & \\
\hline Log Likelihood & -446.355 & & & -616.766 & & \\
\hline$L R$ test & \multicolumn{3}{|c|}{$\chi^{2}(4)=17.87, p<0.00$} & \multicolumn{3}{|c|}{$\chi^{2}(18)=138.89, \mathrm{p}<0.00$} \\
\hline Pseudo-R ${ }^{2}$ & 0.047 & & & 0.120 & & \\
\hline
\end{tabular}

Notes: Robust standard errors are reported. The empirical specification [1b] includes regional and industry dummies. The marginal effects are calculated at the means of the independent variables. (*,**,***) denote statistical significance at the $1 \%, 5 \%$ and $10 \%$, respectively, against a two-sided alternative. 
The goodness of fit measures for both estimated models are satisfactory as presented in Table 2. However, the empirical model (1a) is the basic model that values influences of only some of the HRM functions on organizational performance ( $n=497)$. Following the theoretical and empirical literature on this topic (Chatzimouratidis, Theotokas, \& Lagoudis, 2012); (Dany, Guedri, \& Hatt, 2008); (Zupan \& Kaše, 2005) and the availability of the data used (see Table 1), three HRM policies are extracted for further analysis. Those are policies related to expansion and reduction of employees, to training and development, as well as to recruitment and retention of skilled and unskilled workers.

The first policy is approximated by a change in employment that is measured as a percentage change in the number of employees at the end of 2008 and 2007. This variable is positive and statistically significant $(\mathrm{p}<0.01)$. On-the-job training variable is positive, but statistically insignificant $(p<0.14)$. A variable on recruitment of skilled employees has a negative sign, indicating that the potential shortages of the skilled labour force may negatively influence organizational performance, but this variable is not statistically significant $(p<0.55)$. On the contrary, interviewed firms did not report problems with recruitment of unskilled labour. This variable is positive and statistically significant $(\mathrm{p}<0.09)$.

The econometric specification (1b) was estimated with the expanded sample of firms $(n=716)$ that allows for using a broader set of explanatory factors which may determine changes in organizational performance. Four variables, such as employment change $(\mathrm{p}<0.01)$, sales and revenues $(\mathrm{p}<0.01)$, market demand and competition $(\mathrm{p}<0.01)$, as well as the management of firms $(p<0.01)$, have statistically significant positive influences on organisational performance of growing firms, whereas location has negative influence $(p<0.01)$. Further, it is revealed that firm age has a 'u-shaped' relationship with organizational performance, while, for instance, organizational size is not significant. The joint significance of the terms that capture organizational size is rejected based on the test statistic $\left[\chi^{2}(3)=1.86\right.$, $\mathrm{p}<0.60]$. On the other hand, firm age terms are jointly significant as confirmed by the test statistic $\left[\chi^{2}(2)=6.00\right.$, $\mathrm{p}<0.05]$. It is also interesting to notice that an opposite finding related to the influence of on-the-job training on organizational performance is estimated in the expanded model. The sign of the coefficient is negative, but it is statistically insignificant $(\mathrm{p}<0.45)$.

The discussion of the results obtained by estimating the empirical specifications (1a) and (1b) will be provided in section 4.3 .

\subsection{Results for the HRD model}

Transitional reforms in former socialist countries have induced substantial changes in the organizational structure of firms. Large organizations, in particular, have had a rigid HRD department with 'underdeveloped strategic dimension' of HRM that was not served to 'support business needs' of firms (Zupan \& Kaše, 2005, p. 885). After the privatization of enterprises, new dimensions and much better defined functions of HRM were introduced throughout the practices of foreign owned firms, as well as throughout the practices of subsidiaries of multinational companies (MNCs) (Cooke, Wood, Psychogios, \& Szamosi, 2011); (Horwitz, 2011 ). Their involvement into the economy of transitional countries changed the structure of the whole corporate sector. By exploring the specification depicted in Table 3, we are able to examine to what extent the role of HRD departments in the firms operating in Serbia is changing.

The goodness of fit measures reported in Table 3 confirms the reliability of the estimated binary probit model. However, we have started the analysis by estimating a probit model with the dependent variable that indicates whether the firm has developed a strategy or a plan for HRM. This model failed to pass the LM test for normality $\left[\chi^{2}(2)=12.511\right.$, $\mathrm{p}<0.002]$. Because of this, we decided to use a new variable that captures those firms that have HRD departments as a dependent variable. The LM test provides satisfactory results for the normality of the residuals $\left[\chi^{2}(2)=4.165\right.$, $\left.p<0.125\right]$.

The results confirmed that large- and medium-sized organizations, as well as the scope of revenues, location near to the capital city and foreign ownership significantly determine a firm's decision to establish the HRD department in its organization. All the coefficients are statistically significant at conventional levels. It is also found that the variable firm age is not significant. This result is a bit naive given that the organizations evolve over time (Carley, 1992), but also it cannot be proved by exploring only the cross-section data set. By excluding the terms, age of firm and age of firm squared, the estimation results presented in Table 3 are not substantially changed. For the reestimated model pseudo- $\mathrm{R}^{2}=0.223, \log$ likelihood $=-269.71$ and joint explanatory power of predictors $\left[\chi^{2}(10)=121.94, \mathrm{p}<0.00\right]$ have confirmed that the specification reported in Table 3 may be also considered as satisfactory.

\subsection{Discussion of estimation results}

The theoretical hypothesis that claims that HRM policies such as the decision to invest in HRD, the decision to optimize the number of employees, as well as the decisions related to recruitment and retention of skilled and unskilled workers - may affect the overall organizational performance, and accordingly enhance competitive advantage of an organization, is partially empirically validated. The marginal effect of the change in employment indicates that this variable increases the probability of experiencing growing organizational performance by 52 percentage points (see column 4 , Table 2). This result can be considered overestimated having in mind that the sample threshold was set at 5 and more employees, but this result reveals that optimization of the number of employees is more important from the perspective of 
Table 3: Binary probit estimates (dependent variable: HRD, yes=1). Source: Author's calculation

\begin{tabular}{|l|c|c|c|}
\hline Variable & Coefficient & Standard Error & Marginal Effects \\
\hline Age & 0.003 & 0.006 & 0.0006 \\
\hline $\mathrm{Age}^{2} / 100$ & 0.001 & 0.005 & 0.0001 \\
\hline Log of revenues & $0.156^{*}$ & 0.054 & 0.030 \\
\hline Large organization & $0.960^{*}$ & 0.318 & 0.258 \\
\hline Medium organization & $0.478^{* * *}$ & 0.258 & 0.104 \\
\hline Small organization & 0.099 & 0.251 & 0.019 \\
\hline Micro organization & - & 0.168 & 0.029 \\
\hline Private ownership & 0.165 & 0.154 & 0.077 \\
\hline Foreign capital & $0.348^{* *}$ & 0.128 & 0.053 \\
\hline Capital city & $0.263^{* *}$ & 0.750 & \\
\hline Constant & $-4.133^{*}$ & & \\
\hline & & & \\
\hline Observations & 794 & & \\
\hline Log Likelihood & -268.867 & & \\
\hline$L M$ test for normality & \multicolumn{3}{|l}{} \\
\hline$L R$ test & $\chi^{2}(2)=4.165, \mathrm{p}<0.125$ & & \\
\hline Pseudo-R & $\chi^{2}(12)=128.41, \mathrm{p}<0.00$ & & \\
\hline
\end{tabular}

Notes: Robust standard errors are reported. The empirical specification includes four industry dummies. The marginal effects are calculated at the means of the independent variables. (*, **, ***) denote statistical significance at the 1\%, 5\% and 10\%, respectively, against a two-sided alternative.

employees is more important from the perspective of a firm than all other HRM policies. In part, these findings are in line with trends that were recorded in the overall economy. Namely, the 2008 Labour Force Survey data indicated an increase in the employment rate in the Serbian labour market as well (Ognjenović, 2013). The theoretical expectation that the investment in HRD has statistically significant positive effect on organizational performance of growing firms is not empirically confirmed.

Some empirical studies found that HRD practices observed through 'employee commitment and competence' have strong positive effects on business performance of firms in South Korea (Sung \& Choi, 2014, p. 863), whereas some other empirical studies estimated a negative correlation between trainings and business performances of firms, such as turnover, in a developed economy, based on a mathematical simulation approach (Glance, Hogg, \& Huberman, 1997). Evidently, recruitment policies have diverse effects on the probability of being in the group of firms with growing organisational performance. More specifically, firms that experienced difficulties to fill job vacancies with skilled labour found this a negative influence on organizational performan- ce, whereas those firms that demanded unskilled workers have not experienced difficulties and rated this as a factor of positive influence on business performance.

We need more clarity with regard to the potential influence of on-the-job training to enhance organizational competitive advantage. Based on the Slovenian case, Zupan \& Kaše (2005, p. 889) concluded that the expected effect of training on organizational performance can be considered as negligible, because they do not fill an existing gap in knowledge that would give a competitive advantage to firms in the future. Some preliminary findings for Serbia, obtained from the Cranet survey, show that HRD departments alone are responsible for training and development of employees in their organizations in barely 6 percent of cases. Line managers still retain a major responsibility for this HRM function (Svetlik, et al., 2010, p. 824). In line with previous findings, empirical results presented in this paper lead to the conclusion that the effect of on-the-job training on the probability of being in the group of firms with growing organizational performance is still weak in Serbia.

Firms situated in the urban areas experienced more difficulties than their peers. This variable decreases the proba- 
bility to belong to the group of firms with growing organizational performance by 16.2 percentage points (see column 7 , Table 2). The theoretical hypothesis that being situated near the capital city has a positive effect on organizational performance did not find empirical support. The joint significance of regional dummies, which are not reported in Table 2, was rejected by a result of the test statistic $\left[\chi^{2}(2)=4.27, \mathrm{p}<0.12\right]$. In contrast, empirical results for the case of Russia, for instance, depicted significantly positive influence of the capital city on firm performance (Judge, Naoumova, \& Douglas, 2009, p. 1747). In addition, the joint significance of industry dummies was not confirmed as indicated by the computed test statistic $\left[\chi^{2}(3)=0.87, \mathrm{p}<0.83\right]$.

Furthermore, we tested the hypothesis that firm age follows a 'u-shaped' relationship with organizational performance. This hypothesis was empirically confirmed because the joint impact of the firm age terms is statistically significant and increases the probability that a firm belongs to the group of organizations with good business performance by 0.4 percentage points. Namely, this means that firm performance changes over time and depends in part on internal organizational capability for change that would lead to the improvement of competitive advantage of a 'growing firm' in the future (Judge, Naoumova, \& Douglas, 2009).

A theoretical hypothesis on the positive influence of a set of financial and business indicators on overall organizational performance was empirically tested and accepted. Firms perceived the increasing revenues, market and competitive environment, as well as business decisions of the top management as the factors that unambiguously have supported their growing business performance. Increasing market demand and fostering a competitive environment, for instance, increases the probability of being in the group of firms with growing organizational performance by 0.5 percentage points (see column 7, Table 2).

Finally, it is interesting to notice that the hypothesis that proposed that private ownership, as well as the inflow of foreign capital into the corporate sector in Serbia, increases the probability of being in the group of organizations with growing business performance is not empirically supported. For instance, Cooke, et al. (2011) concluded that the MNCs in Central and Eastern Europe due to the crisis may be more 'reluctant' to invest in human resources and accordingly more cautious in providing information about business performance. However, it is assumed in this paper that the post crisis recession did not significantly affect the survey results because the data collection was conducted during the first quarter of 2009.

Examining the estimation results of the second empirical model that brings more knowledge about the strategic approach to HRM functions in organizations in Serbia, one may draw several conclusions. Large- and medium-sized organizations are more likely to have HRD departments and some written strategy or plan that intent to be a 'framework' for managing human potential. This result is additionally su- pported by the significant effect of a variable that measures the realization of firms' sales and revenues. A very important result is that some modernization in HRM may be expected to be introduced through changes in the ownership structure of organizations.

Namely, private organizations are 2.9 percentage points, whereas those run by the foreign capital are 7.7 percentage points more likely to report that they have HRD departments integrated into their organizational structure (see column 4, Table 3). Geographical location of a firm accordingly becomes significant, because organizations situated in or near to the capital city are 5.3 percentage points more likely to report presence of HRD departments in the organizational structure. Firm age, on the other hand, does not affect the decision of a firm to establish a HRD department. This result is not so surprising bearing in mind that the cross-section data set is used in the empirical analysis and that HRD functions are usually better developed in large organizations. Implicitly, one may conclude that the variable that represents large organizations 'captures' the influence of the variable firm age. However, the longitudinal data would be more promising in searching for the answer to the question at which point of organization's life the organization gets the HRD department.

This paper fulfils the existing gap in research studies on the influence of HRM on the creation of a sustainable competitive advantage through discussing the policies and practices as well as examining the level of the development of organizational structure. The survey of the relevant literature in this field outlines some theoretical implications for boosting organizational performance. Further research is needed in order to check for robustness and reliability of the conclusions drawn in this paper. Some practical implications of the presented results arise from the fact that both the stabile and growing organizations need continuously well trained human resources as well as strategically oriented and integrated business policies. This way they can contribute to creating the knowledge- and innovation-driven economies.

\section{Conclusion}

The primary goal of this paper is twofold. Firstly, it deals with the impact of factors, such as HRM policies and practices, financial and business indicators, as well as firm characteristics on organizational performance. Then, it examines which factors determine the decisions of firms to integrate HRD departments into their organizational structure. There is a body of literature that provides findings that different HRM approaches may induce some positive internal changes in the organizations which contribute to the improvement of their competitive advantage in the future (Cooke, Wood, Psychogios, \& Szamosi, 2011); (Dany, Guedri, \& Hatt, 2008); (Judge, Naoumova, \& Douglas, 2009); (Sung \& Choi, 2014); (Zupan \& Kaše, 2005). 
A common conclusion, based on the selected literature, is that those firms that are aware of the importance of HRM functions pay more attention to their development.

On the contrary to advanced western economies where human resource outcomes are usually measured by turnover (Glance, Hogg, \& Huberman, 1997) and firm performance by the dynamics of 'hard' indicators like financial and accounting indicators of the firm's position in balance sheets, Zupan \& Kaše (2005) suggest that balance of 'hard' financial and 'soft' nonfinancial indicators would be more appropriate for measuring organizational performance in transitional countries. Their explanation lies in the fact that these countries are more exposed to transitional shocks, suffer more from illiquidity and low profitability, have higher unemployment, low labour mobility, etc. Due to the effects of the recent economic crisis there are more empirical studies that consider nonfinancial factors very important for organizational performance (Sung \& Choi, 2014). In addition, because of the specificities of transitional countries, organizational changes in firms have to be examined systematically based on longitudinal data.

Following the survey of theoretical and empirical literature, several hypotheses are posed and empirically tested. The microeconometric framework includes ordered probit and binary probit statistical models. The data come from the survey based on a representative sample of enterprises operating in Serbia. The effects of four groups of factors, including ( $i$ ) HRM policies and practices, (ii) financial and business indicators, (iii) location, and (iv) firm characteristics, on organizational performance are examined. Factors, such as optimization of the number of employees, sales and revenues, firm age, increasing market demand and competitive environment, as well as the 'right decisions' of the top management are found to be significantly positive for boosting organizational performance. The analysis did not provide empirical evidence that on-the-job training, firm size, industry or region has statistically significant influence on organizational performance. When the basic model of organizational performance is estimated, HRM policies related to optimization of the number of employees and the decision to recruit less skilled workers have significantly positive influence on, while difficulties to find high skilled workers were perceived as negative for boosting organizational performance. Likewise, significance of on-thejob training for boosting organizational performance was not empirically supported in this model. An auxiliary model shown that large- and medium-sized firms, firms with high level of revenues, privately owned, foreign and those located in or near to the capital city are more likely to have HRD departments.

The majority of empirical studies surveyed in this paper are developed in the framework of the multivariate analysis. The approach followed in this research relies on the general probability models and can be considered as a novelty. However, the variables used in the empirical mo- dels have been previously determined, and so the determinants selected from the array of HRM policies and practices were already defined, leaving no place for adding new explanatory factors or adjusting the measuring scale of the variables. Another limitation of the empirical research presented in this paper arises from the fact that the current data set represents only enterprises from Serbia. Further research efforts should be oriented towards conducting comparative analyses involving more countries. Also, the longitudinal data sets would be more informative for such types of analyses that would investigate how HRM policies and practices contribute to creating a sustainable competitive advantage of firms through their influence on organizational performance.

\section{Acknowledgement}

The financial support from the Ministry of Education, Science and Technological Development of the Republic of Serbia through the research projects European integrations and social and economic changes in Serbian economy on the way to the EU (no. III-47009) and Challenges and prospects of structural changes in Serbia: Strategic directions for economic development and harmonization with EU requirements (no. OI-179015) is gratefully acknowledged. The author thanks two anonymous reviewers and the editors of this journal for helpful suggestions.

\section{References}

Acemoglu, D. \& Pischke, J.-S. (1999). Beyond Becker: training in imperfect labour markets. The Economic Journal 109(453), F112-F142, http://dx.doi. org/10.1111/1468-0297.00405

Acemoglu, D. \& Pischke, J.-S. (1998). Why do firms train? Theory and evidence. Quarterly Journal of Economics 113(1), 79-119, http://dx.doi. org/10.1162/003355398555531

Bahtijarević Šiber, F. (1999). Menadžment ljudskih potencijala. Zagreb: Golden Marketing.

Barney, J.B. (1995). Looking inside for competitive advantage. The Academy of Management Executive, 9(4), 49-61.

Barney, J.B. \& Clark, D.N. (2007). Resource-Based Theory: Creating and Sustaining Competitive Advantage. Oxford et al.: Oxford University Press.

Barron, M.J., Berger, C.M. \& Black, A.D. (1999). Do workers pay for on-the-job training?. The Journal of Human Resources, 34(2), 235-252, http://dx.doi. org/10.2307/146344

Barrett, A. \& O'Connell, P. (2001). Does training generally work? The returns to in-company training. Industrial and Labor Relations Review, 54(3), 647-662, http://dx.doi.org/10.2307/2695995 
Bartel, A.P. (2000). Measuring the employer's return on investment in training: evidence from the literature. Industrial Relations, 39(3), 502-524, http://dx.doi. org/10.1111/0019-8676.00178

Becker, G.S. (1962). Investment in human capital: a theoretical analysis. The Journal of Political Economy, 70 (Supp.), 9-49.

Becker, B.E. \& Gerhart, B. (1996). The impact of human resource management on organizational performance: progress and prospects. Academy of Management Journal 39(4), 779-801, http://dx.doi.org/10.2307/256712

Blundell, R., Dearden, L., Meghir, C. \& Sianesi, B. (1999). Human capital investment: the returns from education and training to the individual, the firm and the economy. Fiscal Studies 20(1), 1-23, http://dx.doi.org/10.1111/j.1475-5890.1999.tb00001.x

Carley, K. (1992). Organizational learning and personnel turnover. Organization Science 3(1), 20-46, http://dx. doi.org/10.1287/orsc.3.1.20

Cedefop (2010). Skills Supply and Demand in Europe: Medium-Term Forecast up to 2020. Luxembourg: Publications Office of the European Union. Retrieved October 30, 2014 from http://www.cedefop.europa.eu

Cerović, B. (Ed.). (2006). Privatisation in Serbia: Evidence and Analysis. Belgrade: Faculty of Economics and CID.

Chatzimouratidis, A., Theotokas, I. \& Lagoudis, N.I. (2012). Decision support systems for human resource training and development. The International Journal of Human Resource Management, 23(4), 662-693, http://dx.doi.org/10.1080/09585192.2011.561235

Cooke, L.F., Wood, G., Psychogios, G.A. \& Szamosi, T.L. (2011). HRM in emergent market economies: evidence and implications from Europe. Human Resource Management Journal, 21(4), 368-378, http://dx.doi. org/10.1111/j.1748-8583.2011.00181.x

CRANET (2011). Cranet Survey on Comparative Human Resource Management: International Executive Report 2011. Cranfield, UK: Cranet Network at Cranfield University. Retrieved October 30, 2014 from http:// www.cranet.org

Dany, F., Guedri, Z. \& Hatt, F. (2008). New insights into the link between HRM integration and organizational performance: the moderating role of influence distribution between HRM specialists and line managers. The International Journal of Human Resource Management 19(11), 2095-2112, http://dx.doi. org/10.1080/09585190802404320

EBRD (2013). Transition Report 2013. London: European Bank for Reconstruction and Development. Retrieved October 25, 2014 from http://www.ebrd.com/transitionreport

Eurofound (2012). Fifth European Working Conditions Survey. Luxembourg: Publications Office of the European Union, http://dx.doi.org/10.2806/34660

European Commission (2014). European Competitivene- ss Report 2014: Helping Firms Growth. Luxembourg: Publications Office of the European Union. Retrieved November 3, 2014 from http://ec.europa.eu/enterprise/ policies/industrial-competitiveness/competitiveness-analysis/europeancompetitiveness-report/index_ en.htm

Finkelstein, S., \& Peteraf, A.M. (2007). Managerial activities: a missing link in the managerial discretion theory. Strategic Organization 5(3), 237-248, http://dx.doi. org/10.1177/1476127007079975

Finkelstein, S., \& Hambrick, D.C. (1990). Top management team tenure and organizational outcomes: the moderating role of managerial discretion. Administrative Science Quarterly, 35(3), 484-503, http://dx.doi. org/10.2307/2393314

Gerhart, B., \& Milkovich, G.T. (1990). Organizational differences in managerial compensation and financial performance. Academy of Management Journal, 33(4), 663-691, http://dx.doi.org/10.2307/256286

Glance, N.S., Hogg, T. \& Huberman, B.A. (1997). Training and turnover in the evolution of organizations. Organization Science, 8(1), 84-96.

Greene, H.W. (2000). Econometric Analysis, Fourth Edition. Upper Saddle River (USA): Prentice Hall International, Inc.

Grund, C. \& Martin, J. (2012). Determinants of further training - evidence for Germany. The International Journal of Human Resource Management, 23(17), 3536-3558. http://dx.doi.org/10.1080/09585192.2011 .654347

Horwitz, M.F. (2011). Future HRM challenges for multinational firms in Eastern and Central Europe. Human Resource Management Journal, 21(4), 432-443, http://dx.doi.org/10.1111/j.1748-8583.2011.00185.x

Institute for Economic and Social Policy Research, et al. (2009). Research Study: Forecasts on the Labour Market in Serbia [In Serbian: Prognoze kretanja na tržištu rada Srbije]. Belgrade: ESPI.

Jensen, M.C. \& Murphy, K.J. (1990). Performance, pay and top management incentives. The Journal of Political Economy, 98(2), 225-264.

Jovičić, M. (2005). Privatization effects on labour market in Serbia: bottlenecks of the transition process. Economic Annals, 50(167), 55-75.

Judge, Q.W., Naoumova, I. \& Douglas, T. (2009). Organizational capacity for change and firm performance in a transition economy. The International Journal of Human Resource Management, 20(8), 1737-1752, http:// dx.doi.org/10.1080/09585190903087107

Mincer, J. (1994). Human capital: a review. In C. Kerr \& P.D. Staudohar (Eds.), Labor Economics and Industrial Relations: Markets and Institutions (pp. 109-141). Cambridge, Mass. (USA): Harvard University Press.

Mincer, J. (1962). On-the-job training: costs, returns, and some implications. The Journal of Political Economy, 
$70(5), 50-79$.

Nelson, R.R. \& Phelps, E.S. (1966). Investment in humans, technological diffusion, and economic growth. American Economic Review, 56(2), 69-75.

OECD. (2014). OECD Employment Outlook 2014. Paris: OECD Publications. http://dx.doi.org/10.1787/empl_ outlook-2014-en

Ognjenović, K. (2013). Employment and the functioning of the labour market in Serbia. In I. Stošić, S. Redžepagić, C. Berthomieu \& J.S. Andrade (Eds.), Economic Science on the Crossroad: Proceedings from the International Scientific Conference on the Occasion of the 55th Anniversary of the Institute of Economic Sciences (pp. 589-600). Belgrade: Institute of Economic Sciences.

Romer, P. (1990). Human capital and growth: theory and evidence. Carnegie-Rochester Conference Series on Public Policy, 32(1), 251-286, http://dx.doi.org/10.1016/0167-2231(90)90028-J

Sung, S.J. \& Choi, J.N. (2014). Multiple dimensions of human resource development and organizational performance. Journal of Organizational Behavior, 35(6), 851-870. http://dx.doi.org/10.1002/job.1933

Svetlik, I., Barišić, A.F., Kohont, A., Petković, M., Mirić Aleksić, A., Slavić, A., Vaupot, Z. \& Poór, J. (2010). Human resource management in the countries of the former Yugoslavia. Review of International Comparative Management, 11(5), 807-833.
Williamson, O.E. (1963). Managerial discretion and business behavior. American Economic Review, 53(5), 1032-1057.

World Economic Forum. (2014). The Global Competitiveness Report 2014-2015. Geneva: World Economic Forum. Retrieved October 25, 2014 from http://www. weforum.org/gcr

World Economic Forum. (2009). The Global Competitiveness Report 2009-2010. Geneva: World Economic Forum. Retrieved January 22, 2015 from http://www. weforum.org/gcr

Zupan, N. \& Kaše, R. (2005). Strategic human resource management in European transitional economies: building a conceptual model on the case of Slovenia. The International Journal of Human Resource Management, 16(6), 882-906, http://dx.doi. org/10.1080/09585190500120525

Kosovka Ognjenović is a PhD researcher in the field of labour economics and applied microeconometrics at the University of Belgrade. She also holds the position of a research associate in the Institute of Economic Sciences in Belgrade. She studied economics at the University of Zagreb (Croatia) and at the University of Belgrade (Serbia). Her main research interests are currently in labour economics, behaviour of private households and firms and applied microeconometrics. She is author and co-author of scientific and professional articles published in journals, books and conference proceedings. 


\section{Appendix}

Table 1A: Correlation matrix (Source: own)

\begin{tabular}{|c|c|c|c|c|c|c|c|c|c|c|c|c|c|c|c|c|c|c|}
\hline$ㅇ$ & & & & & & & & & & \&̊ & & & & & & & & \\
\hline$a$ & & & & & & & & & $\underset{-}{8}$ & $\frac{\stackrel{*}{n}}{\stackrel{2}{0}}$ & & & & & & & & \\
\hline$\infty$ & & & & & & & & $\underset{8}{8}$ & 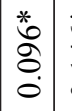 & $\begin{array}{l}\stackrel{*}{6} \\
\stackrel{+}{+} \\
\dot{0}\end{array}$ & & & & & & & & \\
\hline$r$ & & & & & & & $\underset{8}{8}$ & 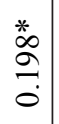 & $\mid$ & 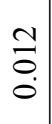 & $r$ & & & & & & & ○ \\
\hline 6 & & & & & & 8 & 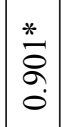 & $\begin{array}{l}* \\
\infty \\
\stackrel{0}{0} \\
\dot{0}\end{array}$ & 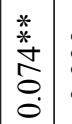 & $\begin{array}{l}8 \\
8 \\
0\end{array}$ & 6 & & & & & & $\stackrel{8}{8}$ & 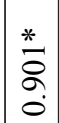 \\
\hline in & & & & & \&: & $\begin{array}{l}0 \\
8 \\
0 \\
0 \\
1\end{array}$ & $\mid \begin{array}{l}0 \\
2 \\
0\end{array}$ & 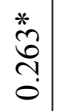 & $\mid \begin{array}{l}\vec{a} \\
\dot{0} \\
\dot{0}\end{array}$ & $\begin{array}{l}\stackrel{Y}{J} \\
\stackrel{0}{0}\end{array}$ & in & & & & & $\underset{8}{8}$ & \begin{tabular}{|l|}
$*$ \\
$\infty$ \\
2 \\
0 \\
0 \\
0
\end{tabular} & $\begin{array}{l}* \\
\infty \\
0 \\
0 \\
0\end{array}$ \\
\hline$\nabla$ & & & & \begin{tabular}{l}
8 \\
\hdashline \\
\hdashline
\end{tabular} & $\begin{array}{l}0 \\
0 \\
0 \\
0 \\
0\end{array}$ & 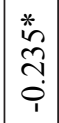 & 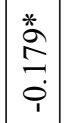 & 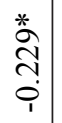 & \begin{tabular}{l}
$*$ \\
\multirow{2}{*}{} \\
8 \\
0 \\
0 \\
1
\end{tabular} & $\begin{array}{l}\infty \\
\stackrel{\infty}{0} \\
0\end{array}$ & $\nabla$ & & & & $\underset{8}{8}$ & 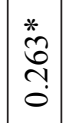 & \begin{tabular}{|l|}
0 \\
8 \\
0 \\
0 \\
1
\end{tabular} & $\begin{array}{l}0 \\
\text { ஜ } \\
0\end{array}$ \\
\hline$m$ & & & $\underset{8}{8}$ & 官 & $\mid \begin{array}{c}* \\
\stackrel{*}{0} \\
\stackrel{0}{0} \\
\dot{0}\end{array}$ & \begin{tabular}{|c|}
$\infty$ \\
0 \\
0 \\
0 \\
1
\end{tabular} & $\begin{array}{l}m \\
0 \\
0 \\
0 \\
1\end{array}$ & \begin{tabular}{|c|}
$*$ \\
0 \\
0 \\
0 \\
0 \\
0
\end{tabular} & $\begin{array}{l}0 \\
0 \\
0 \\
i\end{array}$ & $\begin{array}{l}\stackrel{*}{*} \\
\stackrel{*}{\hat{0}} \\
0 \\
0\end{array}$ & $m$ & & & $\stackrel{8}{8}$ & $\begin{array}{l}0 \\
0 \\
0 \\
0 \\
0\end{array}$ & 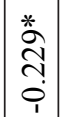 & 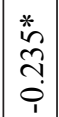 & $\frac{*}{2}$ \\
\hline$N$ & & $\begin{array}{l}8 \\
\vdots \\
-\end{array}$ & 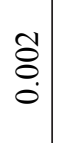 & 号 & 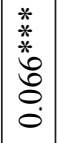 & \begin{tabular}{|c|}
$*$ \\
$\stackrel{*}{n}$ \\
\\
$\stackrel{1}{1}$ \\
\end{tabular} & 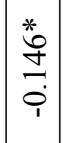 & $\stackrel{*}{\stackrel{*}{\Xi}}$ & $\begin{array}{l}\stackrel{*}{*} \\
\stackrel{*}{*} \\
\stackrel{S}{0} \\
\stackrel{0}{0}\end{array}$ & \begin{tabular}{l}
$*$ \\
$*$ \\
\multirow{*}{*}{} \\
$\infty$ \\
0 \\
0
\end{tabular} & $\sim$ & & $\underset{-}{8}$ & \begin{tabular}{|l}
$\stackrel{*}{ \pm}$ \\
\multirow{1}{*}{} \\
\\
\end{tabular} & \begin{tabular}{|l}
$*$ \\
$\infty$ \\
\\
$\vdots$ \\
0
\end{tabular} & $\begin{array}{l}\stackrel{*}{\sigma} \\
\stackrel{\tilde{t}}{0} \\
\dot{0}\end{array}$ & 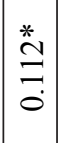 & $\stackrel{*}{\stackrel{*}{a}} \underset{0}{0}$ \\
\hline- & 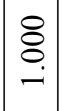 & \begin{tabular}{l}
$*$ \\
\multirow{2}{*}{} \\
$\infty$ \\
$\stackrel{0}{0}$ \\
0
\end{tabular} & 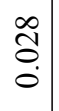 & 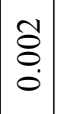 & $\begin{array}{l}n \\
0 \\
0 \\
0\end{array}$ & $\begin{array}{l}\hat{\widehat{a}} \\
\dot{0} \\
\dot{1}\end{array}$ & $\begin{array}{l}\infty \\
0 \\
0 \\
0\end{array}$ & 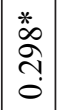 & 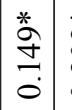 & 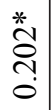 & - & \begin{tabular}{l}
8 \\
\hdashline \\
\\
-
\end{tabular} & $\left|\begin{array}{c}\stackrel{*}{\tilde{N}} \\
\stackrel{N}{0}\end{array}\right|$ & 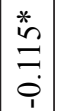 & 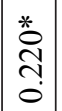 & $\begin{array}{l}* \\
\stackrel{*}{\alpha} \\
\stackrel{\infty}{0} \\
0\end{array}$ & $\stackrel{*}{\stackrel{*}{N}}$ & $\stackrel{*}{\stackrel{*}{I}}$ \\
\hline $\begin{array}{l}0 \\
\frac{\infty}{0} \\
\frac{\pi}{\pi} \\
\frac{\pi}{2}\end{array}$ & 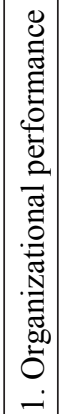 & 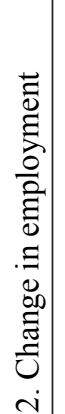 & 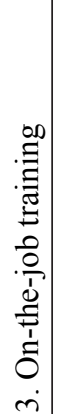 & 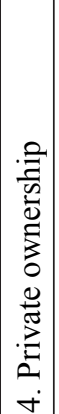 & 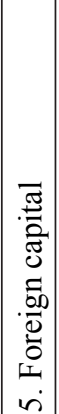 & 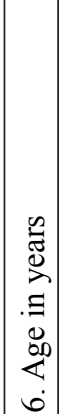 & 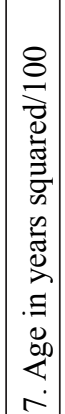 & $\mid \begin{array}{c} \\
\\
0 \\
0 \\
\Xi \\
0 \\
0 \\
0 \\
0 \\
0 \\
0 \\
00 \\
0 \\
0 \\
\infty \\
\infty\end{array}$ & 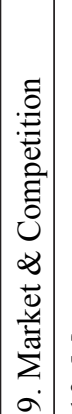 & 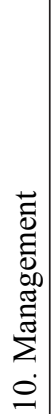 & 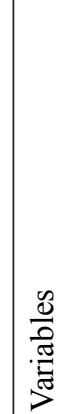 & 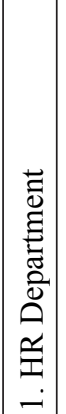 & 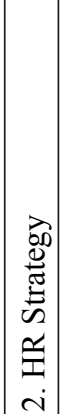 & 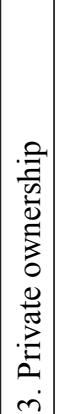 & 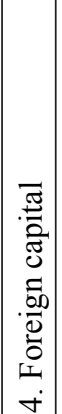 & 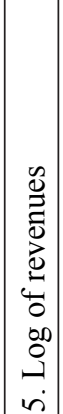 & 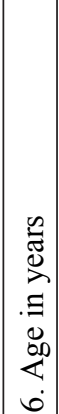 & 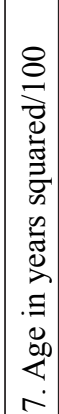 \\
\hline
\end{tabular}

Notes: $(*, * *, * *)$ denote statistical significance at the $1 \%, 5 \%$ and $10 \%$, respectively, against a two-sided alternative. 